\title{
Molecular characterisation of Australasian isolates of aquatic birnaviruses
}

\author{
Kelly R. Davies, Kenneth A. McColl ${ }^{*}$, Lin-Fa Wang, Meng Yu, Lynette M. Williams, \\ Mark St. J. Crane
}

CSIRO Livestock Industries, Australian Animal Health Laboratory, Private Bag 24, Geelong, Victoria 3220, Australia

\begin{abstract}
An aquatic birnavirus, first isolated in Australia from farmed Atlantic salmon in Tasmania in 1998, has continued to be re-isolated on an infrequent but regular basis. Due to its low pathogenicity, there has been little urgency to undertake a comprehensive characterisation of this aquatic birnavirus. However, faced with possible incursions of any new aquatic birnaviruses, specific identification and differentiation of this virus from other, pathogenic, aquatic birnaviruses such as infectious pancreatic necrosis virus (IPNV) are becoming increasingly important. The present study determined the nucleic acid sequence of the aquatic birnavirus originally isolated in 1998, as well as a subsequent isolate from 2002. The sequences of the VP2 and VP5 genes were compared to that of other aquatic birnaviruses, including non-pathogenic aquatic birnavirus isolates from New Zealand and pathogenic infectious pancreatic necrosis virus isolates from North America and Europe. The deduced amino acid (aa) sequences indicate that the Australian and New Zealand isolates fall within Genogroup 5 together with IPNV strains Sp, DPL, Fr10 and N1. Thus, Genogroup 5 appears to contain aquatic birnavirus isolates from quite diverse host and geographical ranges. Using the sequence information derived from this study, a simple diagnostic test has been developed that differentiates the current Australian isolates from all other aquatic birnaviruses, including the closely related isolates from New Zealand.
\end{abstract}

KEY WORDS: Aquatic birnavirus · Infectious pancreatic necrosis virus $\cdot$ Phylogenetic relationships Resale or republication not permitted without written consent of the publisher

\section{INTRODUCTION}

Viruses in the family Birnaviridae belong to 3 genera: Aquabirnavirus, Avibirnavirus and Entomobirnavirus (Delmas et al. 2005). The genus Aquabirnavirus is the largest and most diverse of these genera, and aquatic birnaviruses have been isolated from a large number of different aquatic animal species, both marine and freshwater, throughout the world (Hill \& Way 1995, Reno 1999). Natural disease caused by or associated with aquatic birnaviruses has been reported mainly in finfish, and these pathogenic aquatic birnaviruses have been responsible for major economic losses within aquaculture industries worldwide (Bernard \& Brémont 1995). The type species for the genus Aquabirnavirus is infectious pancreatic necrosis virus (IPNV; Wolf et al. 1960), which causes infectious pancreatic necrosis (IPN) in salmonids. Initially, IPN was defined as an acute, contagious disease resulting in high mortality in young salmonid fish (Hill \& Way 1995). Since then, however, a number of viruses serologically related to IPNV but causing no apparent disease have been detected in non-salmonid species, including a number of finfish species, molluscs and crustaceans (Reno 1999). Aquatic birnaviruses that do not cause disease in salmonid species are often termed IPNV-like or, preferably, aquatic birnaviruses (Hill \& Way 1995).

Aquatic birnaviruses are non-enveloped viruses characterized by a bisegmented double-stranded RNA genome (Dobos 1995). The smaller Segment B encodes VP1, the RNA polymerase of the virus (Dobos et al. 1979). Segment A contains 2 overlapping open reading frames (ORF; Duncan et al. 1987). The small ORF 
encodes VP5, an anti-apoptosis protein (Hong et al. 2002), while the large ORF encodes a polyprotein that, when cleaved, forms 3 viral proteins: pVP2, a nonstructural protein (NS) and VP3 (Dobos 1995). NS is a protease that cleaves the polyprotein while the VP3 protein is an internal component of the capsid (Heppell et al. 1992). The VP2, a component of the outer capsid, is formed by cleavage of the pVP2 precursor upon virus maturation (Dobos 1995). VP2 is the major structural and antigenic protein and, as such, is of particular taxonomic importance (Heppell et al. 1992, 1995).

Despite occurring worldwide and in a number of different host species, most aquatic birnaviruses are antigenically related (Hill \& Way 1995). Serological studies based on reciprocal neutralization assays with polyclonal antisera have identified 2 serogroups, A and B (Hill \& Way 1995). Most aquatic birnaviruses belong to Serogroup A, which contains 9 serotypes (A1 to A9). The type species of Serogroup A viruses is IPNV. A number of serotypes of IPNV have been recorded from finfish in the Asian region (Ahne 1994). In general, these IPNV isolates were most closely related to the Sp, West Buxton and Ab serotypes within Serogroup A. While most serotypes are geographically localized, there appears to be no correlation between serotype and host species (Reno 1999). A number of antigenically unrelated isolates belong to Serogroup B, and, in general, there is far less known about these viruses (Reno 1999). A similar lack of knowledge applies to Serogroups C (John \& Richards 1999) and D (Dixon et al. 2008), which have been recognised more recently.

Until recently, few investigations into the relationship between genetic and serological classifications of aquatic birnaviruses existed. Heppell et al. (1992) compared a $310 \mathrm{bp}$ region at the VP2 and NS junction of 17 Serogroup A IPNV isolates, and they proposed that 3 genogroups existed within Serogroup A. More recently, Blake et al. (2001a,b) examined the genetic relationship of $28 \mathrm{IPNV}$ isolates that represented all serotypes of Serogroup A that were drawn from wide geographical and host origins. This investigation focused on the VP2 region and demonstrated that, in fact, 6 genogroups existed within Serogroup A. It was also demonstrated that unique signature aa residues, which distinguish particular serotypes, existed within the VP2 region (Blake et al. 2001a,b). Since then, a 7th genogroup, including isolates mainly from Japan and Korea, has also been proposed (Zhang \& Suzuki 2004, Nishizawa et al. 2005).

For the Australasian region, IPNV has remained exotic. While aquatic birnaviruses have been isolated in New Zealand on a regular basis since 1987 (Tisdall \& Phipps 1987, Anderson 1995), the first isolation of an aquatic birnavirus in Australia was in 1998 during health surveillance of farmed and wild fish in Tasmania (Crane et al. 2000). At that time, limited immunocytochemical studies in cell culture were undertaken with a panel of monoclonal antibodies in an attempt to compare serological classification of the Australian isolate with that of some known IPNV isolates (Crane et al. 2000). To date, neither Australian nor New Zealand isolates have been associated with clinical signs of disease (Crane et al. 2000). In addition, the DPL isolate was reported from finfish in Thailand (Blake et al. 2001a,b). While the cytochemical studies could not clearly assign the Australian isolate to any of the major serotypes of IPNV, limited sequence analysis suggested that the isolate was most closely related to the N1, Fr-21 and Ab strains in Serogroup A. Since the initial identification, regular surveillance has seen the virus isolated on a regular basis, always from apparently healthy farmed salmon and never outside Macquarie Harbour, Tasmania, Australia.

In order to better understand the relationship between these isolates and others from around the world, this paper describes the complete nucleotide (nt) sequence of Segment A of TAB98, the original Australian isolate, together with the coding region of Segment B. In addition, the VP2 sequences of a subsequent Australian isolate (TAB02) and 2 New Zealand isolates (NZ6 and NZ10) were also obtained to determine the genomic relationship of Australasian isolates with other Aquabirnavirus isolates found worldwide, including IPNV and marine aquatic birnaviruses.

\section{MATERIALS AND METHODS}

Virus isolates. The isolate designated TAB98 was first detected in 1998 during routine health surveillance of Tasmanian farmed Atlantic salmon Salmo salar from Macquarie Harbour. Hence, it was originally called the Macquarie Harbour isolate or Tasmanian aquatic birnavirus (TAB; Crane et al. 2000). The virus was isolated from wild marine fish and poorly growing, 18 mo old, farmed Atlantic salmon. The isolate designated TAB02 was isolated from healthy farmed Atlantic salmon from Macquarie Harbour during routine health surveillance in 2002. Eight additional Australian isolates of TAB, isolated from a variety of hosts and geographical locations, were also used in this study (see Fig. 4). NZ6 was isolated from Quinnat salmon Oncorhynchus tshawytscha in New Zealand during export certification testing (Tisdall \& Phipps 1987). NZ10 was isolated from wild-caught turbot Psetta maxima (M. Hine pers. comm.). The Erwin strain of IPNV was kindly provided by Drs. Barry Hill and Keith Way, CEFAS, Weymouth Laboratory, UK, and has been used in our laboratory as a highly patho- 
genic positive control. As there was no published sequence available for the gene encoding the VP2 protein on the Erwin strain, this region was also sequenced for future laboratory reference. Virus identity was confirmed by growth in cell culture, followed by electron microscopy and immunoperoxidase assays using specific antibodies as described previously (Crane et al. 2000).

Virus propagation. Inoculum was prepared by thawing aliquots $(10 \mu \mathrm{l})$ of frozen stock tissue culture supernatant for each isolate and diluting in $5 \mathrm{ml}$ of Eagle's minimum essential medium containing Earle's salts (Gibco-BRL) supplemented with $10 \mathrm{mM}$ hepes buffer (ICN Biomedical), $2 \mathrm{mM}$ glutamine (ICN Biomedical), $100 \mathrm{IU}$ penicillin $\mathrm{ml}^{-1}, 100 \mu \mathrm{g}$ streptomycin $\mathrm{ml}^{-1}$ (Sigma-Aldrich) and $2 \%(\mathrm{v} / \mathrm{v})$ foetal bovine serum (Thermo Trace). For each isolate, the culture medium on $90 \%$ confluent cultures of the CHSE-214 cell line, grown in $25 \mathrm{~cm}^{2}$ flasks (Corning), was replaced by this inoculum, and the cultures were incubated at $15^{\circ} \mathrm{C}$ with an atmosphere of $5 \% \mathrm{CO}_{2} / 95 \%$ air until complete viral cytopathic effect was observed. Cell culture medium was harvested, centrifuged at $1000 \times g$ for $10 \mathrm{~min}$ at $4^{\circ} \mathrm{C}$ and supernatant fluid stored at $-80^{\circ} \mathrm{C}$ until use.

RNA extraction and preparation of cDNA. RNA was extracted from supernatants using the QiaAmp Viral RNA Extraction Kit (Qiagen) according to the manufacturer's instructions. Complementary DNA (cDNA) was synthesised using avian myeloblastosis virus (AMV) reverse transcriptase (Promega). Briefly, $1 \mu \mathrm{l}$ of RNA was mixed with $0.5 \mu$ l deionized formamide, pulse-centrifuged and incubated at $100^{\circ} \mathrm{C}$ for $40 \mathrm{~s}$, then chilled on ice. The sample was mixed with $19.5 \mu \mathrm{l}$ master mix containing $1 \mu \mathrm{l}$ of random hexamer $(5 \mathrm{mg}$ $\mathrm{ml}^{-1}$ ) (Promega), $4 \mu \mathrm{l}$ of $5 \times$ AMV reaction buffer (Promega), $4 \mu \mathrm{l}$ of $1.25 \mathrm{mM}$ dNTPs, $20 \mathrm{U}$ of AMV reverse transcriptase (Promega), $40 \mathrm{U}$ of RNA inhibitor (RNAsin; Promega) and $7 \mu$ sterile distilled water. Reactions were incubated at $25^{\circ} \mathrm{C}$ for $10 \mathrm{~min}$ followed by $42^{\circ} \mathrm{C}$ for $30 \mathrm{~min}$ with a final incubation at $65^{\circ} \mathrm{C}$ for $5 \mathrm{~min}$.

Polymerase chain reaction (PCR). PCRs consisted of $1 \mu \mathrm{l}$ cDNA with PCR master mix containing $2.5 \mu \mathrm{l} 10 \times$ reaction buffer (Promega), $1.5 \mathrm{mM}$ magnesium chloride (Promega), $4 \mu \mathrm{l}$ of $1.25 \mathrm{mM}$ dNTPs, $1.25 \mathrm{U}$ Taq polymerase (Promega), $1 \mu \mathrm{l}$ of $20 \mu \mathrm{M}$ sense and antisense primers (Table 1) and sterile distilled water to $25 \mu \mathrm{l}$. PCRs were undertaken in a Perkin Elmer thermocycler using cycling conditions as follows: 1 cycle at $94^{\circ} \mathrm{C}$ for $2 \mathrm{~min} ; 35$ cycles at $92.5^{\circ} \mathrm{C}$ for $45 \mathrm{~s}, 58^{\circ} \mathrm{C}$ for $45 \mathrm{~s}$ and $72^{\circ} \mathrm{C}$ for $105 \mathrm{~s}$; and finally 1 cycle at $72^{\circ} \mathrm{C}$ for 7 min. PCR products were visualised on a $2 \%$ TAE (Tris-acetate-EDTA) agarose gel containing $0.5 \mu \mathrm{g}$ ethidium bromide $\mathrm{ml}^{-1}$ (BioRad) under UV irradiation.
After excision from the agarose gel, PCR products were purified using a QIAquick Gel Extraction Kit (Qiagen).

Sequence analysis. Sequences of Segments A and B were determined for TAB98, while for TAB02, NZ6, NZ10 and Erwin isolates, sequencing was restricted to the VP2 region. The general sequencing strategy was to sequence purified overlapping PCR fragments (as described by Blake et al. 2001a,b) using fluorescencebased dideoxy Big Dye terminator chemistry (PE Applied Biosystems). Each PCR fragment was sequenced in each direction at least twice to ensure that an accurate consensus was obtained.

To sequence the Segment A and B termini of TAB98, a modified single primer amplification technique (SPAT) was used (Attoui et al. 2000, Potgieter et al. 2002). First, viral RNA was isolated from partially purified virus. Briefly, tissue culture supernatant with suspended cells (150 ml) was homogenised in a Dounce homogenizer and clarified by low speed centrifugation at $2000 \times g$ for $20 \mathrm{~min}$ at $4^{\circ} \mathrm{C}$. The supernatant was centrifuged 3 more times, each at $18000 \times g$ for $1 \mathrm{~h}$ at $4^{\circ} \mathrm{C}$, then ultracentrifuged at $149000 \times g$ for $70 \mathrm{~min}$ at $4^{\circ} \mathrm{C}$. The resultant pellet was resuspended in a minimal volume of sterile distilled water. RNA was isolated by adding $500 \mu \mathrm{l}$ of the resuspended viral pellet to $12.5 \mu \mathrm{l}$ $20 \mathrm{mg} \mathrm{ml}^{-1}$ Proteinase K and $5 \mu \mathrm{l} 10 \%$ sodium dodecyl sulphate (SDS) and incubating at $37^{\circ} \mathrm{C}$ for $3 \mathrm{~h}$ with occasional vortexing. Total RNA was extracted using phenol and diethylether, ethanol-precipitated and resuspended in $50 \mu \mathrm{l}$ sterile distilled water. Contaminating chromosomal single-stranded RNA was precipitated overnight from the double-stranded RNA (dsRNA) with $2 \mathrm{M}$ lithium chloride as described by Potgieter et al. (2002). The supernatant was ethanolprecipitated and resuspended in $20 \mu \mathrm{l}$ distilled water. Purified dsRNA was visualised on a $2 \%$ TAE agarose gel containing ethidium bromide (BioRad) under UV irradiation, excised and purified as 2 separate segments using QIAquick Gel Extraction Kit (Qiagen).

Each dsRNA segment was ligated to primer PC3 (5' $\mathrm{PO}_{4}$-GGA TCC CGG GAA TTC GG(A) ${ }_{17}-\mathrm{NH}_{2} 3^{\prime}$ ) using $\mathrm{T} 4$ ligase (Promega) at $16^{\circ} \mathrm{C}$ overnight as described previously by Vreede et al. (1998) and Lambden et al. (1992). Primer PC3 contained restriction enzyme sequences with both a poly (dA) tail to facilitate oligo dT priming and a 3 ' terminal $\mathrm{NH}_{2}$-group that prevented concatenation. Ligated segments were purified using the QIAquick PCR purification kit (Qiagen), and cDNA was transcribed using Superscript II (Invitrogen) according to the manufacturer's instructions using primer PC2 (5' $\mathrm{PO}_{4}$-CCG AAT TCC CGG GAT CC-OH $\left.3^{\prime}\right)$ complementary to the anchor site ligated to either end of the segments. Ligated cDNA was amplified by PCR using primer PC2 and gene specific primers of 
Table 1. Primers used in sequencing (A) the full length Segment A of Tasmanian aquatic birnavirus (TAB) and (B) the coding region of Segment B of TAB. Positions of each primer are referenced according to the published sequence of the Jasper strain

(Duncan \& Dobos 1986). ESAx refer to primers designed for end sequencing. ${ }^{*}$ denotes reverse primer. N/A: not applicable

\begin{tabular}{|c|c|c|c|c|}
\hline $\begin{array}{l}\text { Primer } \\
\text { name }\end{array}$ & Sequence $5^{\prime}$ to $3^{\prime}$ & Position & $\begin{array}{l}\text { Amplicon } \\
\text { size (bp) }\end{array}$ & Source \\
\hline \multicolumn{5}{|c|}{ Segment A } \\
\hline $\mathrm{Pb} 9$ & GAG AGC TCT TAC GGA GGA G & 39 & 508 & Blake et al. (2001a) \\
\hline Pa8* & GAC ATC AAG CTG TTG TAG G & 547 & & Blake et al. (2001a) \\
\hline KS3 & GAC GTC GCA GGA CCT GAA G & 371 & 623 & Present study \\
\hline $\mathrm{KS}_{1} \mathrm{R}^{*}$ & ATC TTG GCT GAG ACG CCT CTG & 994 & & Present study \\
\hline P8 & GGA AAT ACG ACA TCC AGA GCT & 421 & 909 & Blake et al. (2001a) \\
\hline $\mathrm{P} 10^{*}$ & CAC AGG ATC ATC TTG GCA TAG T & 1330 & & Blake et al. (2001a) \\
\hline P15 & GAA CGG AGC AAG GAT GAG GTG & 683 & 1076 & Blake et al. (2001a) \\
\hline $\mathrm{P} 12^{*}$ & TGC ACC ACA GGA AAG ATG ACT C & 1759 & & Blake et al. (2001a) \\
\hline KS1 & CAG AGG CGT CTC AGC CAA GAT & 974 & 457 & Present study \\
\hline $\mathrm{KS}_{2} \mathrm{R}^{*}$ & GCA GGT CGC TGG AGA AGT CAG TG & 1431 & & Present study \\
\hline P14 & GTA TCC AAC TAT GAG CTG AT & 1224 & 535 & Blake et al. (2001a) \\
\hline $\mathrm{P} 12^{*}$ & TGC ACC ACA GGA AAG ATG ACT C & 1759 & & Blake et al. (2001a) \\
\hline $\mathrm{KS} 2 \mathrm{~F}$ & TCC GGA AGG TGG CAG CTC CTG TA & 1474 & 316 & Present study \\
\hline $\mathrm{KS}^{*}{ }^{*}$ & GAA TGC CTC GCC TGG TGC ACT T & 1790 & & Present study \\
\hline P17 & CCA GTT CAT CGG AGA TCT CAC & 1544 & 616 & Blake et al. (2001a) \\
\hline $\mathrm{P} 1 \mathrm{R}^{*}$ & GTT CAT GGG CGG CTA TGG CTT T & 2160 & & Blake et al. (2001a) \\
\hline $\mathrm{P} 13$ & GAG TCA TCT TTC CTG GGT GCA & 1738 & 422 & Blake et al. (2001a) \\
\hline $\mathrm{P} 1 \mathrm{R}^{*}$ & GTT CAT GGG CGG CTA TGG CTT T & 2160 & & Blake et al. (2001a) \\
\hline $\mathrm{P} 13$ & GAG TCA TCT TTC CTG TGG TGC A & 1738 & 334 & Blake et al. (2001a) \\
\hline $\mathrm{AK} 2^{*}$ & CCT GGT TGG TTG CCA ATG & 2072 & & Present study \\
\hline $\mathrm{P} 13$ & GAG TCA TCT TTC CTG TGG TGC A & 1738 & 574 & Blake et al. (2001a) \\
\hline P7R* & TCT CAT CAG CTG GCC CAG GTA C & 2313 & & Blake et al. (2001a) \\
\hline AK1 & TGC CAC TCA TCG GCA ACC & 2048 & 557 & Present study \\
\hline G1R* & GCT TTG ACG GCG TCC AGT GA & 2605 & & Present study \\
\hline AK1 & TGC CAC TCA TCG GCA ACC & 2048 & 731 & Present study \\
\hline $\mathrm{G} 2 \mathrm{R}^{*}$ & GCA TTT GGT CTT GGT CGG & 2898 & & Present study \\
\hline G1 & ATA TCA CTG GAC GCC GTC AAA G & 2583 & 315 & Present study \\
\hline $\mathrm{G} 2 \mathrm{R}^{*}$ & GCA TTT GGT CTT GGT CGG GTC & 2898 & & Present study \\
\hline ESA1* & CAA GTA AGT TGC GGT TGC CTT G & 33 & N/A & Present study \\
\hline ESA2* & GAT GCT TGC TGG TCC AGT CTC & 72 & N/A & Present study \\
\hline ESA3 & AGG AGT TCT ACG ACG CAG TTG & 2708 & N/A & Present study \\
\hline ESA4 & TGC CGA GAA TGG AGG AAG AGG & 2857 & N/A & Present study \\
\hline \multicolumn{5}{|c|}{ Segment B } \\
\hline $\mathrm{B} 1 \mathrm{~F} 2$ & ATG TCG GAC ATC TTC AAC TCA C & 101 & 523 & Present study \\
\hline B3R2* & TTC ATT GCC AGT AGC CTG TT & 624 & & Present study \\
\hline $\mathrm{B} 2 \mathrm{~F}$ & CAT TCC ACA AGC CAG ACC ATG AC & 423 & 457 & Present study \\
\hline $\mathrm{B}^{4} \mathrm{R}^{*}$ & CGT CGT GT CTC CTT TGG TTT TG & 880 & & Present study \\
\hline KSB1 & AGC AGA TGG CAA GAC TGA TGG A & 684 & 844 & Present study \\
\hline KSB3* & TTG TGG TGG CAG AAT GGC ACA A & 1528 & & Present study \\
\hline $\mathrm{B} 4 \mathrm{~F}$ & CCG GCC TAC CCT ACA TAG GCA AA & 840 & 769 & Present study \\
\hline${\mathrm{B} 7 \mathrm{R}^{*}}^{*}$ & CTC TTT GGT CAT GGG GTT TGG & 1609 & & Present study \\
\hline KSB2 & TGA CTA GGT CCT GCT CCT GAT & 1230 & 844 & Present study \\
\hline $\mathrm{KSB}^{*}$ & GTT GTT CCA GTC GTC CAG GAA T & 2074 & & Present study \\
\hline $\mathrm{B} 6 \mathrm{~F}$ & CAG GCC ATG ATG TAC TAC C & 1346 & 1094 & Present study \\
\hline B9R2* & GCT CTT TAG CAG GTT GTT CGC & 2440 & & Present study \\
\hline B8F2 & GAA ACA GCA GCA AAA CAC ATG & 1982 & 458 & Present study \\
\hline $\mathrm{B} \mathrm{R}^{*}$ & GCT CTT TAG CAG GTT GTT CGC & 2440 & & Present study \\
\hline ESB1* & CCT GCG TGC TCT TCA TGA GTG & 170 & N/A & Present study \\
\hline ESB2* & ATC CTT TGC GGG TCT GAA GCG & 220 & N/A & Present study \\
\hline ESB3 & CAT TGC GAG ACC AAG CAA AGG & 2316 & N/A & Present study \\
\hline ESB4 & CCG AAG AAC TCG CAG AAC AAC & 2382 & N/A & Present study \\
\hline
\end{tabular}


each segment (Table 1) using a reaction mix as described previously with the following cycling conditions: 1 cycle at $94^{\circ} \mathrm{C}$ for $2 \mathrm{~min} ; 35$ cycles at $94^{\circ} \mathrm{C}$ for $30 \mathrm{~s}$ and at $62^{\circ} \mathrm{C}$ for $2 \mathrm{~min}$. Products were visualized on a $2 \%$ gel with ethidium bromide, excised, purified and sequenced as described above. Sequence data were analysed and managed using Chromas (Techelysium) and Sci Ed Central (Scientific and Educational Software). Accession numbers of sequences generated in this study are included in Table 2. Phylogenetic analyses were undertaken with Sci Ed Central Clone Manager 9 (Scientific and Educational Software).

Development of a diagnostic PCR test. The PCR mixture per sample consisted of the following reagents: $9.5 \mu$ l of water; $12.5 \mu$ of HotStar Taq Master mix; $0.5 \mu \mathrm{l}(20 \mu \mathrm{M})$ of the newly designed primer GABF 5' ACG AAC CCT CAG GAC AA 3' and of primer GABR 5' CAC AGG ATC ATC TTG GCA TAG T 3' (Blake et al. 2001a,b); and $2 \mu$ of cDNA. PCR conditions were as follows: 1 cycle at $94^{\circ} \mathrm{C}$ for $15 \mathrm{~min} ; 35$ cycles at $94^{\circ} \mathrm{C}$ for $45 \mathrm{~s}, 45^{\circ} \mathrm{C}$ for $45 \mathrm{~s}$ and $72^{\circ} \mathrm{C}$ for $2 \mathrm{~min}$; and finally, 1 cycle at $72^{\circ} \mathrm{C}$ for $7 \mathrm{~min}$. Amplified DNA (775 bp) was detected by agarose gel electrophoresis.

Restriction enzyme digestion of a diagnostic aquatic birnavirus PCR product. If a PCR product of the correct size was amplified, the product was eluted from the agarose gel. To $10 \mu \mathrm{l}$ of the eluate were added: $2 \mu \mathrm{l}$ of $10 \times$ reaction buffer, $2 \mu \mathrm{l}$ of BSA $\left(1 \mathrm{mg} \mathrm{ml}^{-1}\right), 10 \mathrm{U}$ of the restriction enzyme $\mathrm{ClaI}$ and water to a final volume of $20 \mu \mathrm{l}$. Digestions were performed at $37^{\circ} \mathrm{C}$ for $1.5 \mathrm{~h}$, followed by incubation at $65^{\circ} \mathrm{C}$ for $15 \mathrm{~min}$ to inactivate the enzyme. Digested and undigested samples were then resolved on an agarose gel containing ethidium bromide and examined under UV illumination. Type strains representing Genogroups 1 to 6 were analysed, including West Buxton, Jasper, VR299, Erwin, He, Can1, Can2, Can3, Te, Ab, Sp and DPL in addition to TAB isolates identified in different host species between 1998 and 2002. Serogroup B viruses TV-1 and an isolate from Limanda limanda (Olesen et al. 1988) were also analysed.

\section{RESULTS AND DISCUSSION}

\section{Sequence analysis of TAB98}

Reverse transcriptase PCR was used to generate 14 overlapping fragments for Segment A and 7 fragments for Segment B of TAB98. Each fragment was then sequenced with both forward and reverse primers, and together, these sequences accounted for 2861 of $3097 \mathrm{bp}$ (93\%) for Segment A and 2313 of 2657 bp (87\%) for Segment B. SPAT was employed to determine terminal sequences of Segment A. Despite numerous attempts on
2 different preparations of RNA, the complete termini of Segment B could not be determined. However, the coding region for Segment B was determined.

A single large ORF within Segment B was identified which encoded the VP1 protein. The VP1 coding region was $2532 \mathrm{nt}$ (844 aa) in length as was the case with IPNV strain Sp and marine aquatic birnavirus (MAB) strain AY-98 (Zhang \& Suzuki 2004). All 3 strains appeared to have one less residue than other IPNV and MAB strains already sequenced. The TAB98 isolate appeared to have a nucleotide deletion at position 2636 (compared with IPNV type strain, Jasper), which resulted in a stop codon. The VP1 region of TAB98 shared the highest identity with Sp (89\% nt, $95 \%$ aa) and the lowest identity with US strains of West Buxton and Jasper (80\% nt, 89\% aa).

Within Segment A, 2 separate but partially overlapping ORF were identified. The smaller ORF, $399 \mathrm{nt}$, encoded the VP5 protein (133 aa). Across the VP5 protein, the TAB98 isolate appeared most similar to the European isolate Fr21 (94\% nt, $86 \%$ aa) and least similar to North American strains Jasper and VR299 (85\% nt, $58 \%$ aa).

The second ORF identified in Segment A encoded the polyprotein (VP2-NS-VP3). If the polyprotein cleavage sites were assumed to be ${ }^{508} \mathrm{~A}^{\mathbf{\nabla}} \mathrm{S}^{509}$ (VP2-NS) and ${ }^{734} \mathrm{~A}^{\boldsymbol{\nabla}} \mathrm{S}^{735}$ (NS-VP3) (Petit et al. 2000), the processed proteins VP2, NS and VP3 would be 508, 225 and 139 aa in length, respectively. Across the entire polyprotein, TAB98 showed the highest identity with IPNV strain Sp (91\% nt, 96\% aa) and the lowest identity with IPNV strain $\mathrm{He}(75 \%$ nt, $85 \%$ aa). However, across the VP2 protein, where more sequence information in GenBank is available, TAB98 showed the highest identity with the 2 NZ isolates (NZ6, NZ10), DPL and Sp (Table 3). Our study supports and extends a previous analysis of TAB98 (Crane et al. 2000), which was based on very limited sequence information (a 459 bp PCR product).

\section{VP2 sequence analyses of other isolates - TAB02, NZ6, NZ10 and Erwin}

Further investigation of other Australasian isolates (TAB02, NZ6 and NZ10) was restricted to the sequence of the VP2 region. Being the major capsid protein, the VP2 contains all neutralizing epitopes and cell attachment sites which determine host and cell range (Lipipun et al. 1989). The VP2 has also been shown to contain the central variable domain, which encompasses 2 hypervariable segments (Heppell et al. 1995). Blake et al. $(2001 \mathrm{a}, \mathrm{b})$ further demonstrated that the VP2 region contains small variable regions, which identify specific serotypes, and they identified highly conserved signature aa residues that distinguish particular serotypes. 


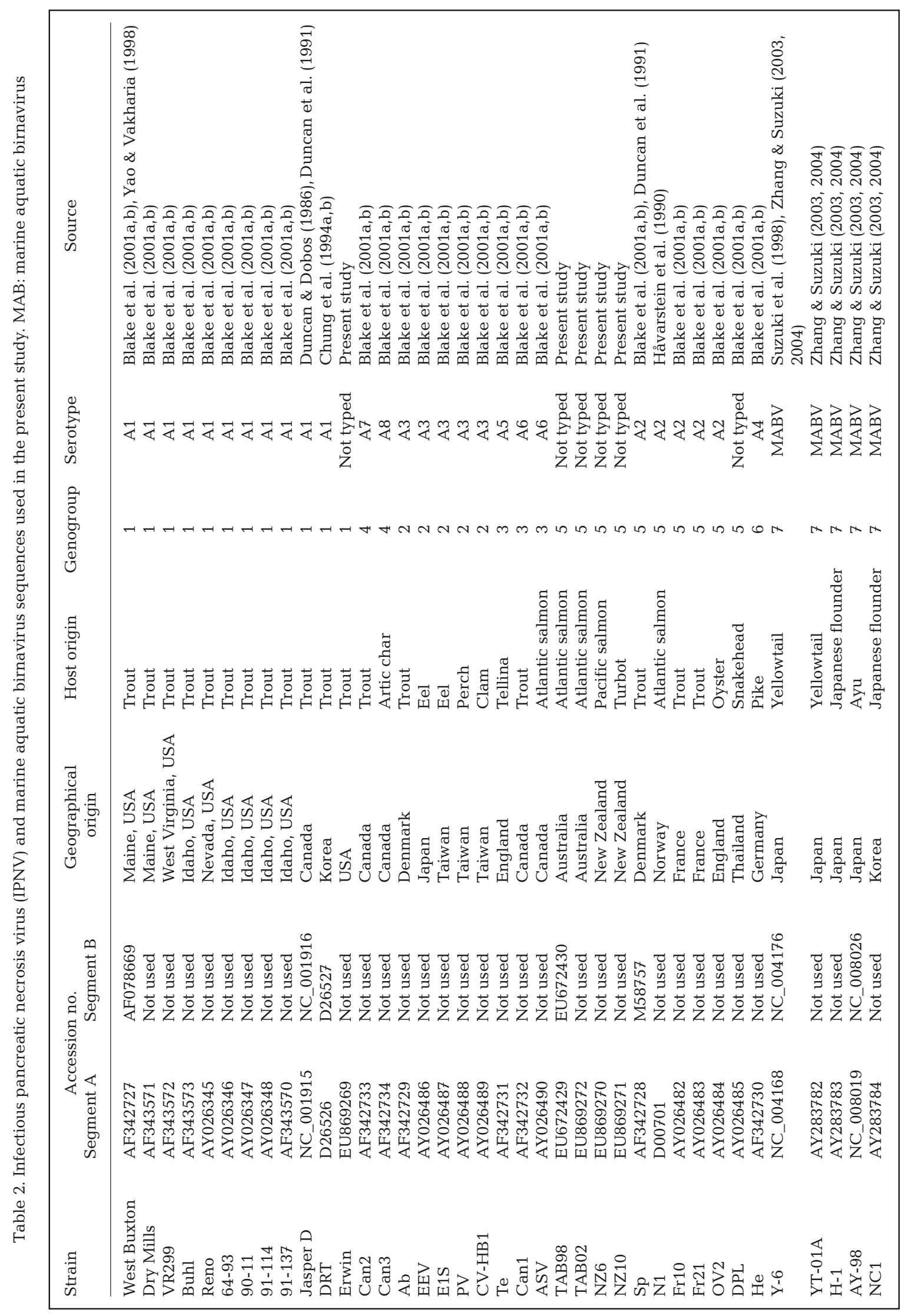


Table 3. Percent nucleotide (lower left) and amino acid (upper right) similarity of the VP2 protein of different strains of aquatic birnavirus

\begin{tabular}{|c|c|c|c|c|c|c|c|c|c|c|c|c|c|c|c|c|}
\hline & TAB98 & TAB02 & NZ10 & NZ6 & DPL & $\mathrm{Sp}$ & Can2 & Can3 & $\mathrm{Ab}$ & Can1 & $\mathrm{Te}$ & Jasper & WB & VR299 & Erwin & $\mathrm{He}$ \\
\hline TAB98 & & 99 & 99 & 98 & 96 & 96 & 89 & 89 & 91 & 92 & 92 & 86 & 86 & 86 & 88 & 85 \\
\hline TAB02 & 99 & & 98 & 98 & 96 & 96 & 89 & 89 & 91 & 92 & 92 & 86 & 86 & 86 & 88 & 84 \\
\hline NZ10 & 97 & 97 & & 99 & 96 & 96 & 89 & 89 & 92 & 92 & 92 & 87 & 87 & 87 & 88 & 85 \\
\hline NZ6 & 94 & 94 & 95 & & 96 & 96 & 89 & 89 & 91 & 92 & 91 & 87 & 87 & 87 & 88 & 85 \\
\hline DPL & 91 & 91 & 92 & 91 & & 97 & 89 & 89 & 90 & 90 & 90 & 86 & 86 & 86 & 87 & 86 \\
\hline $\mathrm{Sp}$ & 91 & 90 & 92 & 91 & 98 & & 89 & 89 & 90 & 90 & 90 & 87 & 87 & 87 & 88 & 86 \\
\hline Can2 & 85 & 84 & 85 & 85 & 84 & 84 & & 97 & 87 & 87 & 87 & 86 & 86 & 86 & 86 & 83 \\
\hline Can3 & 85 & 85 & 85 & 85 & 84 & 84 & 96 & & 87 & 88 & 87 & 86 & 86 & 86 & 86 & 83 \\
\hline $\mathrm{Ab}$ & 86 & 86 & 87 & 86 & 86 & 86 & 82 & 82 & & 90 & 90 & 88 & 88 & 88 & 88 & 82 \\
\hline Can1 & 86 & 86 & 87 & 87 & 86 & 86 & 83 & 84 & 86 & & 95 & 96 & 85 & 86 & 86 & 82 \\
\hline $\mathrm{Te}$ & 86 & 86 & 87 & 87 & 87 & 86 & 82 & 83 & 85 & 91 & & 85 & 85 & 85 & 86 & 83 \\
\hline Jasper & 80 & 79 & 79 & 79 & 79 & 80 & 78 & 78 & 80 & 79 & 74 & & 96 & 99 & 97 & 81 \\
\hline WB & 79 & 79 & 80 & 80 & 79 & 80 & 79 & 79 & 82 & 79 & 78 & 89 & & 96 & 95 & 81 \\
\hline VR299 & 79 & 79 & 79 & 79 & 79 & 80 & 78 & 78 & 80 & 79 & 78 & 99 & 89 & & 97 & 81 \\
\hline Erwin & 83 & 83 & 82 & 81 & 82 & 82 & 79 & 79 & 81 & 80 & 80 & 95 & 87 & 95 & & 82 \\
\hline $\mathrm{He}$ & 75 & 75 & 76 & 76 & 76 & 76 & 75 & 74 & 74 & 74 & 74 & 73 & 73 & 73 & 74 & \\
\hline
\end{tabular}

The sequence of the TAB02 isolate was found to have a $99 \%$ (nt, aa) identity with the TAB98 isolate across the VP2 region (Table 3). Over the 508 aa, alignments revealed 3 aa changes between the 2 isolates at positions 54, 255 and 477, the first being a conserved change and the 2 other changes being significant. These data suggest that the aquatic birnavirus isolates obtained from fish species within Macquarie Harbour on an infrequent but regular basis most likely belong to the same strain, which apparently has not changed significantly over the $4 \mathrm{yr}$ period spanning the isolation of TAB98 and TAB02.

While the TAB found in 2002 was detected during routine health surveillance, this isolate was not recovered from a pinhead fish as was the case with the original isolate in 1998 (Crane et al. 2000). The isolate in 2002 was from healthy Atlantic salmon, showing no overt signs of disease.

Both the 1998 and 2002 TABs were isolated from Atlantic salmon. Following the first isolation in 1998, a number of fish species in Macquarie Harbour were sampled, and TAB was isolated. Limited sequencing was performed on isolates identified from other fish species sampled in 1998, including wild fish. These isolates were found to have $100 \%$ identity with TAB98 at the aa sequence level across the $393 \mathrm{bp}$ sequenced within the hypervariable region (data not shown).

A New Zealand isolate from wild-caught turbot, designated NZ10, showed a high level of identity to TAB98 (97\% nt, 99\% aa), suggesting that the Australian and NZ isolates may have originated from the same source, presumably wild marine species inhabiting the Southern Ocean. A further New Zealand isolate, designated NZ6, was also very similar to the TAB98 isolate (94\% nt ,98\% aa) (Table 3).
Analysis of the VP2 sequence of the Erwin isolate (used as a virulent positive control in our studies) demonstrated greatest identity with the Jasper and VR299 strains of IPNV (Table 3).

\section{Phylogenetic analysis}

To determine how the Australasian isolates were related to other Serogroup A IPNV and MABs, published nucleotide sequences covering the polyprotein ORF for 29 IPNV and 5 MABs were aligned in Clustal X and used to generate a phylogenetic tree using TreeView software (Fig. 1). As demonstrated by Blake et al. (2001a,b), IPNV strains appeared to cluster into 6 genogroups based on geographical and serological similarities. The Australasian isolates fall within Genogroup 5 and appear to be most closely related to the $\mathrm{Sp}$ and N1 strains. In contrast to Genogroup 1, which appears to contain viruses isolated solely from trout in North America (USA and Canada), Genogroup 5 consists of isolates from more diverse geographical and host ranges, viz., from trout in Denmark and France, from Atlantic salmon in Norway, from oysters in UK, from various species including Atlantic salmon in Australia, from Quinnat salmon and turbot in New Zealand and from snakehead in Thailand. Interestingly, the aa sequence of VP2 shows no more than $4 \%$ divergence between isolates within Genogroup 5 as seen in Table 3 . This is in contrast to $9 \%$ divergence between the Australasian isolates and Genogroups 3 and 4 , and 11, 14 and 16\% divergence between the Australasian isolates and Genogroups 2, 1 and 6, respectively.

Full length alignments of the Segment A polyprotein (Fig. 2) revealed that all Australasian isolates investigated in this study had 2 unique aa residues: an argi- 
nine at position 81 and an alanine at position 221 . Blake et al. $(2001 \mathrm{a}, \mathrm{b})$ described a unique glycine at position 76 for all Genogroup 5 isolates. Results from our study demonstrate that not all Genogroup 5 isolates shared this unique signature aa residue. Australasian isolates contained a glutamine at position 76 , as did isolates of Genogroup 3. However, alignments demonstrated that all Genogroup 5 isolates, including Australasian isolates, shared the unique methionine and leucine residues at positions 263 and 361, as described by Blake et al. (2001a,b).

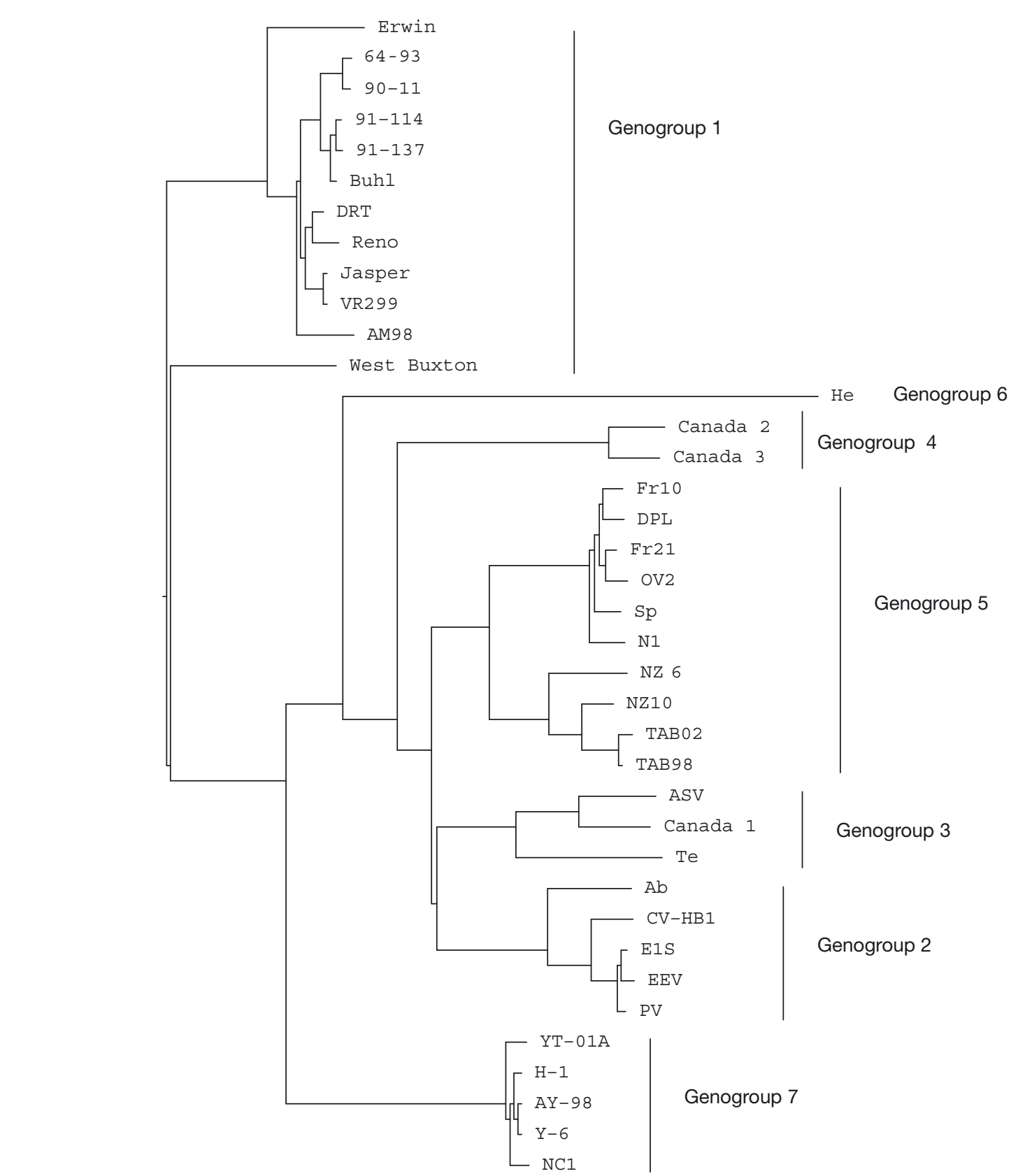

Several studies (Bruslind \& Reno 2000, Santi et al. 2004, Shivappa et al. 2004) have reported the presence of threonine and alanine at positions 217 and 221 of virulent strains, whereas low virulent strains have a proline and alanine at the same residues. As seen in Fig. 2, TAB isolates have a proline and alanine at positions 217 and 221, respectively, indicating low virulence. Bain et al. (2008) recently demonstrated that strains with a proline and alanine at positions 217 and 221, respectively, were in fact highly virulent in field and experimental conditions. These

Fig. 1. Phylogenetic analysis of VP2 sequences of Australasian isolates and of published sequences of strains of infectious pancreatic necrosis virus (IPNV) and marine aquabirnaviruses 


\begin{tabular}{|c|c|c|}
\hline er & 1 & stskatatylrsimlpengpasipdditerhilkqetssynlevsesgsgllvcfpgap \\
\hline VR299 & 1 & 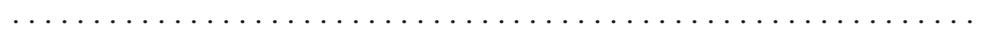 \\
\hline Erwin & 1 & 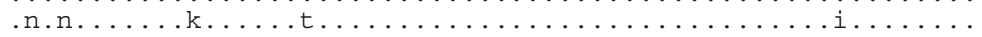 \\
\hline WB & 1 & 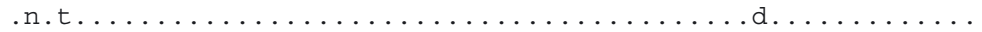 \\
\hline $\mathrm{Ab}$ & 1 & 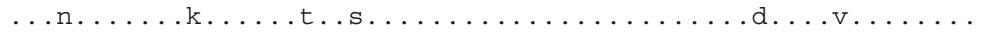 \\
\hline Can1 & 1 & 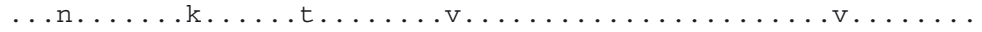 \\
\hline $\mathrm{Te}$ & 1 & 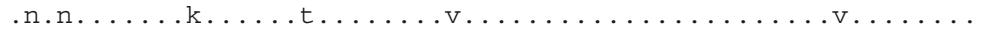 \\
\hline Can2 & 1 & 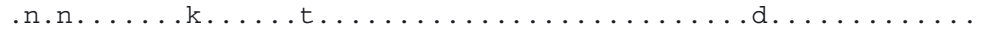 \\
\hline Can3 & 1 & 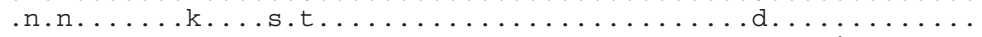 \\
\hline Sp & 1 & 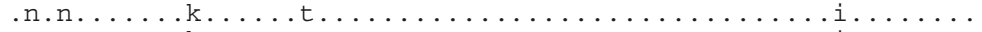 \\
\hline DPL & 1 & 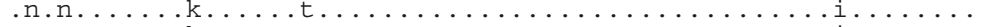 \\
\hline TAB98 & 1 & 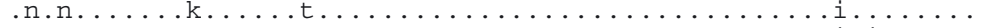 \\
\hline TAB 02 & 1 & 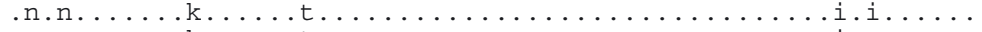 \\
\hline NZ10 & 1 & 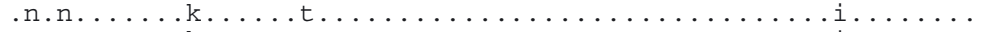 \\
\hline NZ6 & 1 & 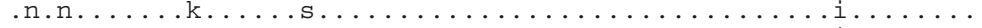 \\
\hline $\mathrm{He}$ & 1 & 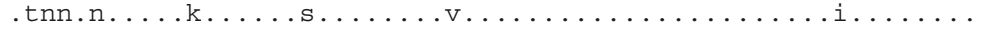 \\
\hline asper & 61 & gsrvgahyrwnlnqtalefdqwletsqdlkkafnygrlisrkydiqsstlpaglyalngt \\
\hline VR299 & 61 & 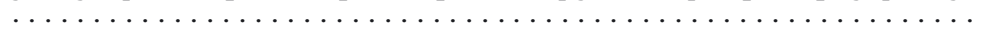 \\
\hline Erwin & 61 & $\ldots \ldots \ldots \ldots$. \\
\hline WB & 61 & 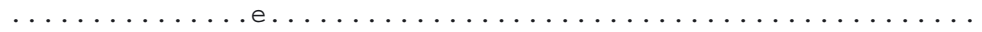 \\
\hline $\mathrm{Ab}$ & 61 & $\ldots \ldots \ldots$. $\ldots$ e. . . . . . . . . . . . . . . . . \\
\hline Can1 & 61 & 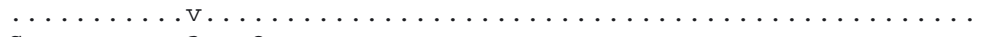 \\
\hline $\mathrm{Te}$ & 61 & 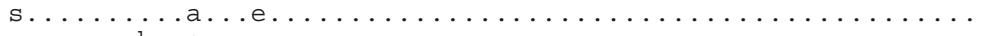 \\
\hline Can2 & 61 & 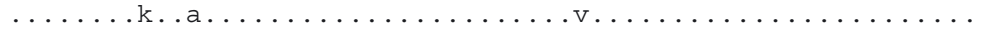 \\
\hline Can3 & 61 & 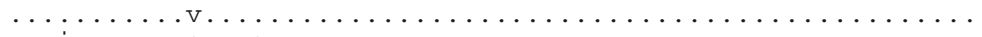 \\
\hline $\mathrm{Sp}$ & 61 & 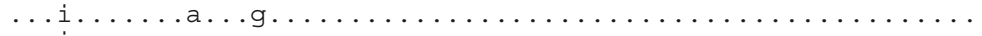 \\
\hline DPL & 61 & 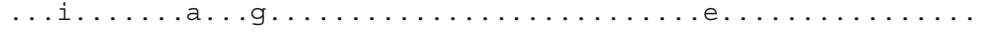 \\
\hline TAB 98 & 61 & 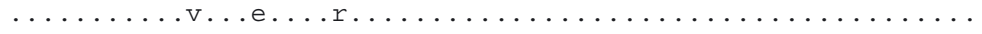 \\
\hline ТАВ 02 & 61 & $\ldots \ldots \ldots$. \\
\hline NZ10 & 61 & $\ldots \ldots \ldots$. \\
\hline NZ6 & 61 & $\ldots \ldots \ldots$. $\ldots$ e. \\
\hline $\mathrm{He}$ & 61 & 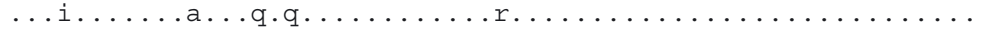 \\
\hline asper & 121 & lnaatfegslsevesltynslmslttnpqdkvnnqlvtkgitvlnlptgfdkpyvrlede \\
\hline VR299 & 121 & 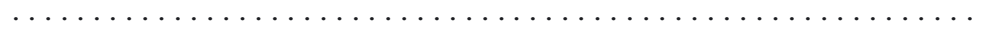 \\
\hline Erwin & 121 & 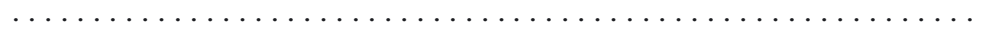 \\
\hline WB & 121 & 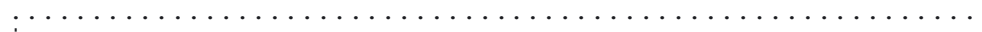 \\
\hline $\mathrm{Ab}$ & 121 & 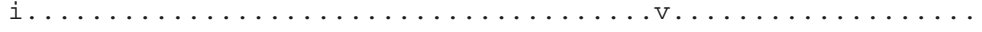 \\
\hline Can1 & 121 & 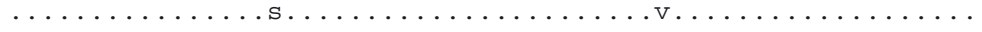 \\
\hline $\mathrm{Te}$ & 121 & 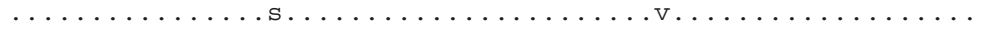 \\
\hline Can2 & 121 & 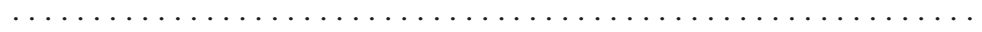 \\
\hline Can3 & 121 & 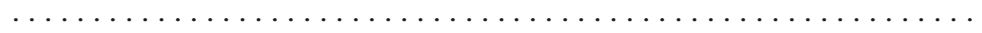 \\
\hline Sp & 121 & 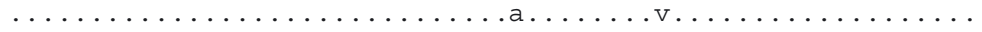 \\
\hline DPL & 121 & 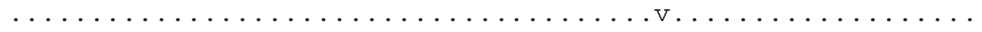 \\
\hline ТАВ98 & 121 & 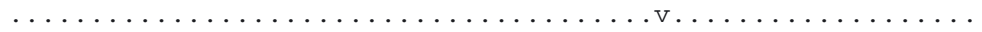 \\
\hline TAB 02 & 121 & 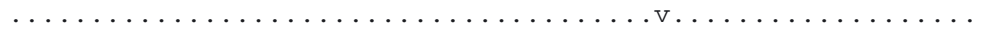 \\
\hline NZ10 & 121 & 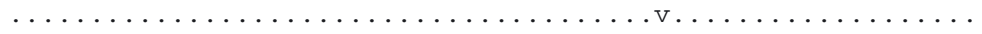 \\
\hline NZ6 & 121 & 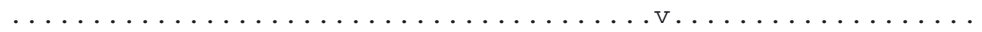 \\
\hline $\mathrm{He}$ & 121 & $i \ldots \ldots \ldots$. . pn.s.......................... \\
\hline Jasper & 181 & tpqgpqsmngarmrctaaiaprryeidlpserlptvaatgtpttiyegnadivnstavtg \\
\hline VR299 & 181 & 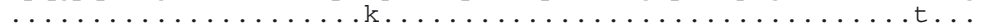 \\
\hline Erwin & 181 & 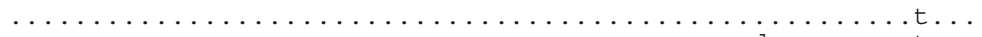 \\
\hline WB & 181 & 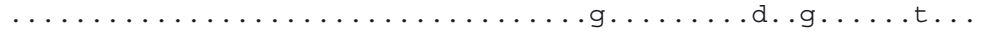 \\
\hline $\mathrm{Ab}$ & 181 & 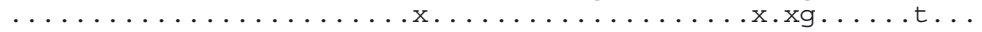 \\
\hline Can1 & 181 & 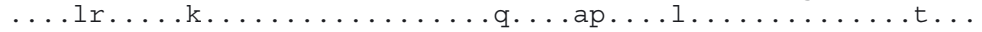 \\
\hline $\mathrm{Te}$ & 181 & 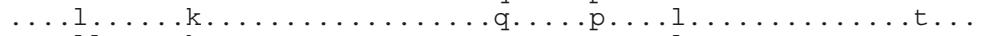 \\
\hline Can2 & 181 & 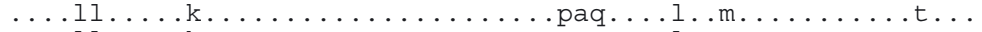 \\
\hline Can3 & 181 & 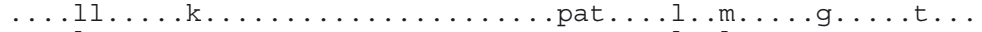 \\
\hline Sp & 181 & 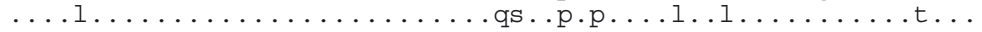 \\
\hline DPL & 181 & 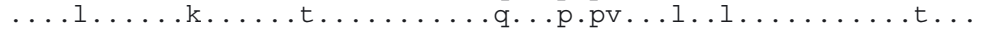 \\
\hline TAB98 & 181 & 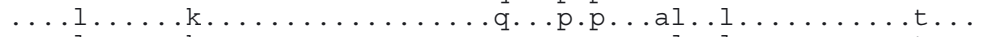 \\
\hline ТАВ02 & 181 & 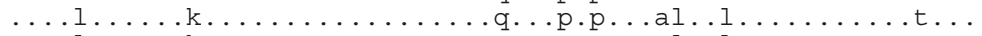 \\
\hline NZ10 & 181 & 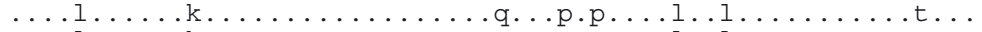 \\
\hline NZ6 & 181 & 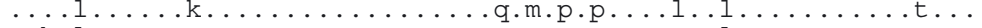 \\
\hline $\mathrm{He}$ & 181 & 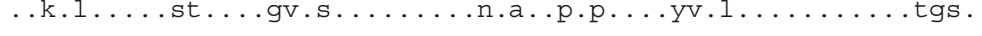 \\
\hline Jasper & 241 & ditfqleaepvnetrfdfilqflgldndvpvvtvtsstlvtadnyrgasakftqsiptem \\
\hline VR299 & 241 & 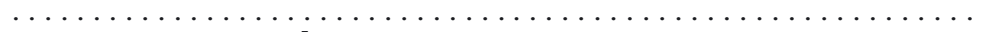 \\
\hline Erwin & 241 & 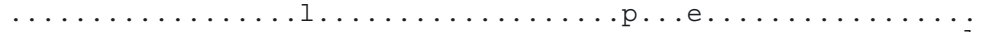 \\
\hline WB & 241 & 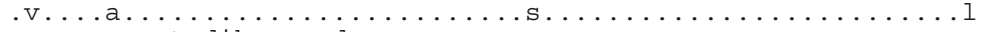 \\
\hline $\mathrm{Ab}$ & 241 & ..s.s.ann.tadik...q.d.....................m.m...n \\
\hline Can1 & 241 & ..n.s.pra.ttd..y..q.d.i.......s...v.a...fq.v........d \\
\hline $\mathrm{Te}$ & 241 & ..n.r.p.a.pad.ky..q.d.v....i...si...v.a..a.fs.v........d \\
\hline Can2 & 241 & ..s.s.ata.aa.t.e.q.d....n.....i.ta.a.ke.hl.v...m.a...s \\
\hline Can3 & 241 & ..s.s.ana.aad.t.k.q.d.....n.....i.ta.a.te.hl.v...m..a...s \\
\hline $\mathrm{Sp}$ & 241 & 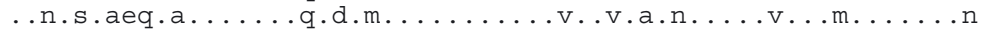 \\
\hline DPL & 241 & ..n.s.aeh.a...k...q.d.m........v..v.a.s...s.v..m.....n \\
\hline & 241 & n.s.adn.pt \\
\hline
\end{tabular}

Fig. 2 (continued overleaf). Amino acid (aa) sequence alignment of Segment A polyproteins. (.) Identical aa residues 


\begin{tabular}{|c|c|c|}
\hline 302 & 41 & .n.s.ads.pt. .q...q.d.m........v. .v.a.....v...m.... \\
\hline NZ10 & 241 & ..n.s.adn.pt..k...q.d.m........v. .v.a.....v...m.... \\
\hline NZ6 & 241 & ..n.s.adn.pt..k...q.d.m........v. .v.a.....v...m.... \\
\hline $\mathrm{He}$ & 241 & ..n.n.qqa.a...k...k.e.....e....v..v.a.ea...i...m... \\
\hline asper & 01 & itkpitrvklayqlnqqtaianaatlgakgpasvsfssgngnvpgvlrpitlvayekm \\
\hline R299 & 01 & 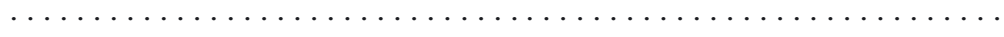 \\
\hline Erwin & 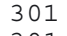 & 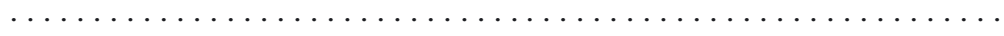 \\
\hline WB & . & 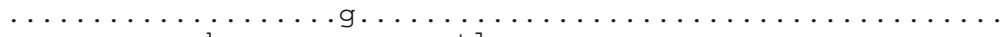 \\
\hline $\mathrm{Ab}$ & 01 & 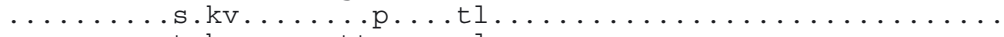 \\
\hline Can1 & 01 & 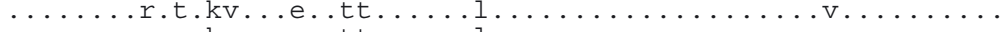 \\
\hline $\mathrm{Te}$ & 01 & 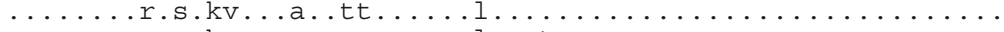 \\
\hline Can2 & 301 & 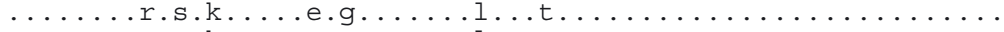 \\
\hline Can3 & 301 & 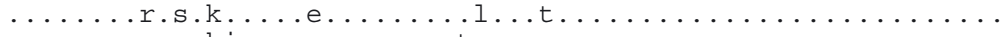 \\
\hline Sp & 01 & $\ldots \ldots \ldots$ s.ki $\ldots \ldots$ g.v. . tm $\ldots \ldots \ldots \ldots \ldots \ldots$ \\
\hline DPL & 01 & 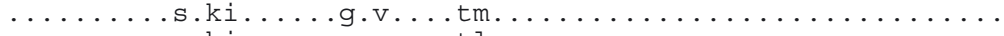 \\
\hline TAB98 & 01 & 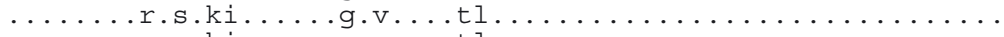 \\
\hline TAB 02 & 01 & 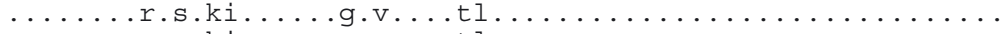 \\
\hline NZ10 & 01 & 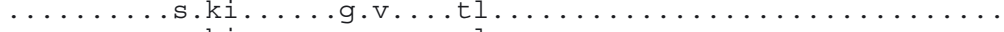 \\
\hline NZ6 & 01 & 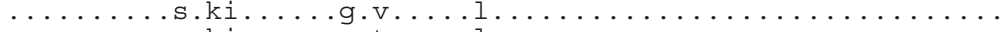 \\
\hline $\mathrm{He}$ & 01 & 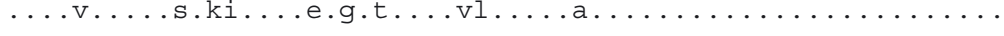 \\
\hline Jasper & 51 & qsiltvagvsnyelipnpdllknmvtkygkydpeglnyakmilshreeldirtvwrte \\
\hline VR2 99 & 61 & 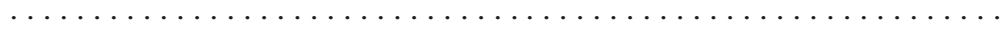 \\
\hline Erwin & 61 & 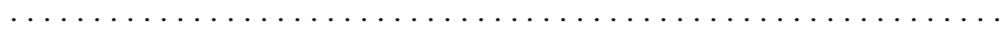 \\
\hline WB & 361 & 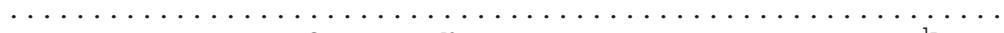 \\
\hline $\mathrm{Ab}$ & 361 & 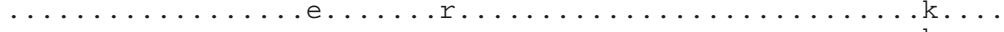 \\
\hline Can1 & 361 & 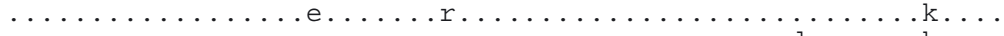 \\
\hline $\mathrm{Te}$ & 361 & 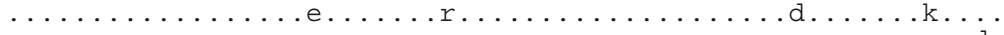 \\
\hline Can2 & 61 & 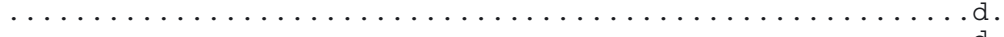 \\
\hline Can3 & 61 & 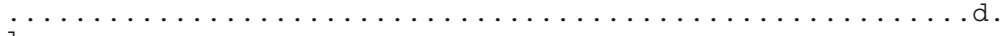 \\
\hline $\mathrm{Sp}$ & 61 & 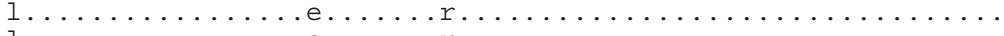 \\
\hline DPL & 51 & 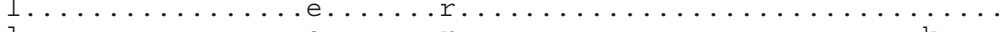 \\
\hline TAB98 & 361 & 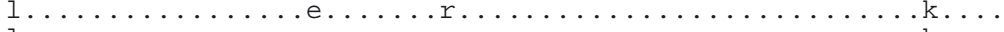 \\
\hline TAB 02 & 361 & 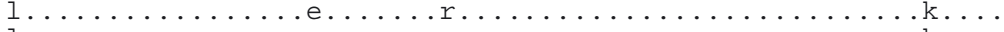 \\
\hline NZ10 & 361 & 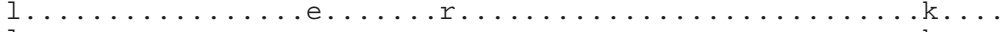 \\
\hline NZ6 & 361 & 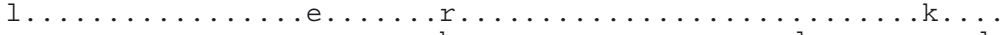 \\
\hline $\mathrm{He}$ & 361 & 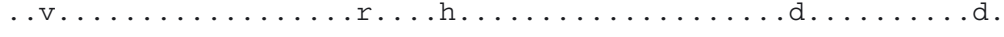 \\
\hline Jasper & & kertrafkeitdftsdlptskawgwrdlvrgirkvaapvlstlfpmaapligaadqf \\
\hline VR299 & 1 & 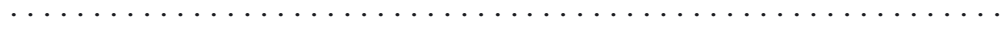 \\
\hline Erwin & 421 & 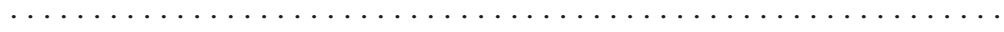 \\
\hline WB & 421 & 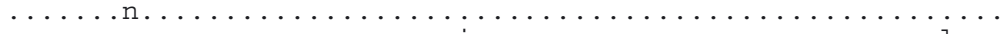 \\
\hline $\mathrm{Ab}$ & 421 & 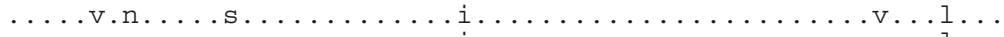 \\
\hline Can1 & 421 & 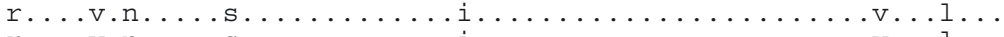 \\
\hline $\mathrm{Te}$ & 421 & 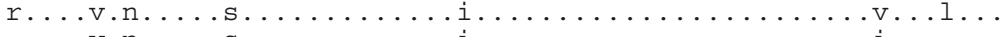 \\
\hline Can2 & 421 & 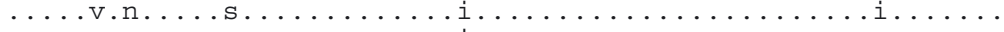 \\
\hline Can3 & 421 & 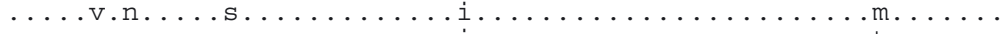 \\
\hline Sp & 421 & 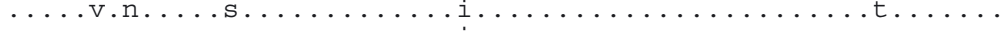 \\
\hline DPL & 421 & 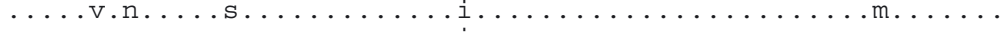 \\
\hline TAB98 & 421 & 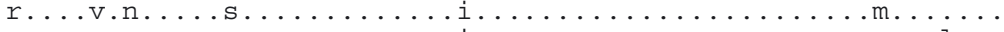 \\
\hline TABO 2 & 421 & 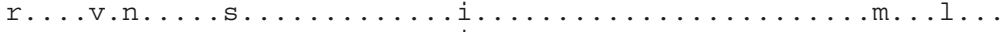 \\
\hline NZ10 & 421 & 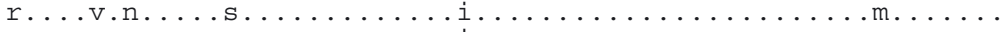 \\
\hline NZ6 & 421 & 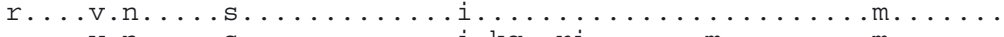 \\
\hline $\mathrm{He}$ & 421 & 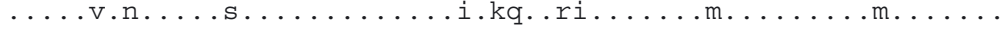 \\
\hline Jasper & 481 & ltktnsaggrylshaaggryhdvmdswasgseagsyskhlktrlesnnyeevelpkpt \\
\hline VR299 & 481 & 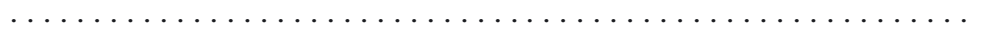 \\
\hline Erwin & 481 & 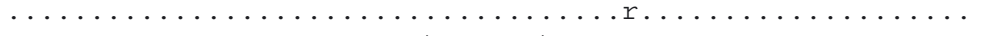 \\
\hline WB & 481 & 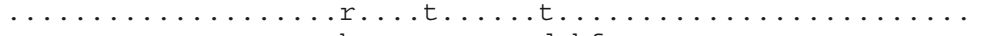 \\
\hline $\mathrm{Ab}$ & 481 & .n......r.m....k.......gpd.kf.qa..n...a.....p.s \\
\hline Can1 & 481 & 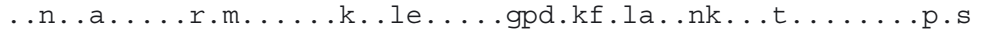 \\
\hline $\mathrm{Te}$ & 481 & 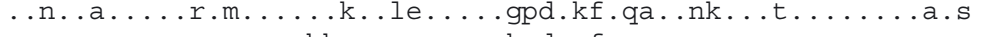 \\
\hline Can2 & 481 & $\ldots$......n.m...hhr...e...kqd.rf.qs..n.......... \\
\hline Can3 & 481 & 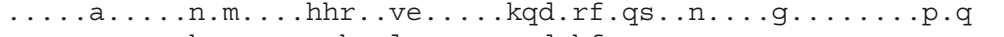 \\
\hline $\mathrm{Sp}$ & 481 & 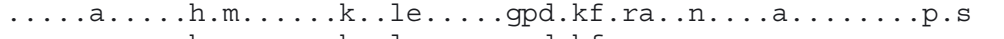 \\
\hline DPL & 481 & .........h.m....k.le...gpd.kf.ra.n.......... \\
\hline TAB 98 & 481 & 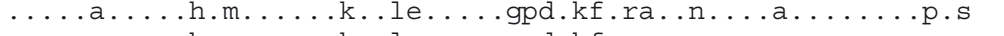 \\
\hline TAB 02 & 481 & .........h.m....k.le...gpd.kf.ra.n.......... \\
\hline NZ10 & 481 & 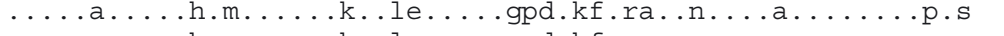 \\
\hline NZ6 & 481 & .........h.m....k.le....gpd.kf.ra..n.........p.q \\
\hline $\mathrm{He}$ & 481 & 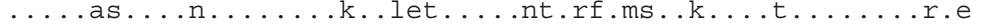 \\
\hline
\end{tabular}

Fig. 2. (continued) 
conflicting observations, together with the fact that $\mathrm{TAB}$ has not caused disease in Atlantic salmon, support the suggestion by Bain et al. (2008) that viral, host and/or environmental factors in addition to specific aa residues influence pathogenicity. TAB has continued to be isolated from salmon sea cages, but its presence has not been associated with elevated mortality rates. However, TAB has never been isolated from hatcheries in Tasmania, and whether it would be pathogenic to salmonids under hatchery conditions in Tasmania is unknown.

The location of the initiation codon of the VP5 protein may vary (data not shown). Magyar \& Dobos (1994) reported that the initiation codon of VP5 is situated at position 68, although Heppell et al. (1995) demonstrated that VP5 expression was strain-dependent and could be initiated from position 68 or 112 . Weber et al. (2001) have since demonstrated, by reverse genetics, that the second in-frame methionine codon is responsible for the initiation of VP5 in VR299, which Shivappa et al. (2004) have also demonstrated in Sp strains. The He strain is the only known IPNV to lack an ORF for VP5 (Heppell et al. 1995).

Alignment of VP5 nt sequences (Fig. 3A) demonstrates that all Australasian Aquabirnavirus isolates and several IPNV strains have a nucleotide deletion at position 106 that alters the reading frame of these isolates when compared to the IPNV type strain, Jasper. One of the IPNV isolates with this deletion (Strain N1) moves back into the original reading frame due to an

\begin{tabular}{|c|c|c|}
\hline $\mathbf{A}$ & & $\downarrow$ \\
\hline Jasper & 68 & ATGGCGAAAGCCCTTTCTAACAAACAACCAACAATTCTTATCTACATGAATCA \\
\hline VR299 & 68 & 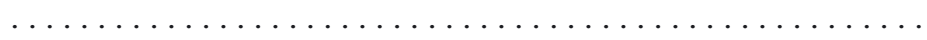 \\
\hline West Buxton & 68 & 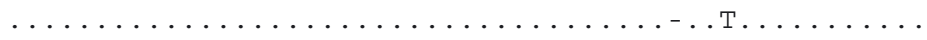 \\
\hline Can2 & 68 & 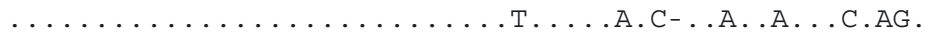 \\
\hline $\mathrm{Ab}$ & 1 & 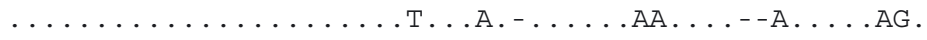 \\
\hline $\mathrm{E} 1-\mathrm{S}$ & 1 & 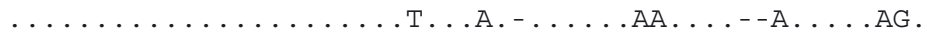 \\
\hline N1 & 79 & $\ldots \ldots \ldots \ldots \ldots \ldots \ldots \ldots \ldots \ldots \ldots$ A. А. . АТАТ. СА. .АС. AG. \\
\hline Fr21 & 68 & 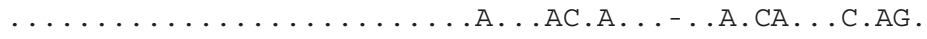 \\
\hline NVI - 001 & 68 & 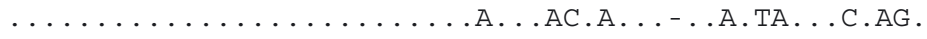 \\
\hline NVI- 011 & 68 & 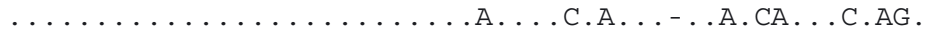 \\
\hline NVI- 013 & 68 & 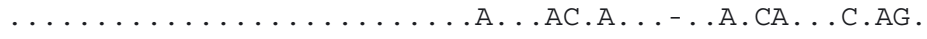 \\
\hline NVI- 015 & 68 & 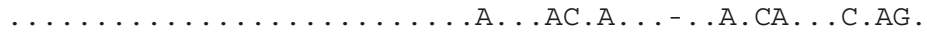 \\
\hline NVI- 016 & 68 & 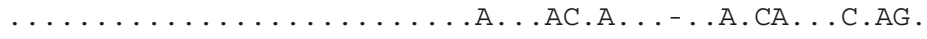 \\
\hline NVI- 020 & 68 & 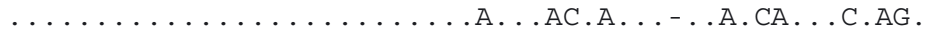 \\
\hline NVI - 023 & 68 & 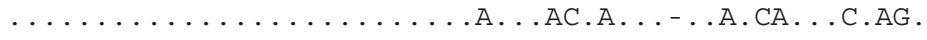 \\
\hline TAB98 & 68 & 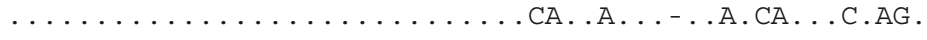 \\
\hline ТАВ02 & 11 & 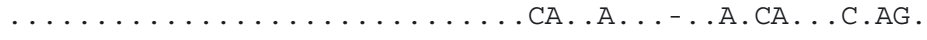 \\
\hline NZ\#6 & 30 & 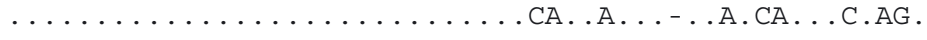 \\
\hline NZ\#10 & 30 & 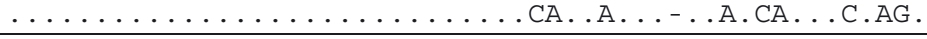 \\
\hline
\end{tabular}

\section{B}

Jasper

VR2 99

West Buxton

Can2

$\mathrm{Ab}$

E1-S

N1

Fr21

NVI - 001

NVI - 011

NVI -013

NVI - 015

NVI - 016

NVI - 020

NVI -023

TAB 98

TAB 02

NZ\#6

NZ\#10

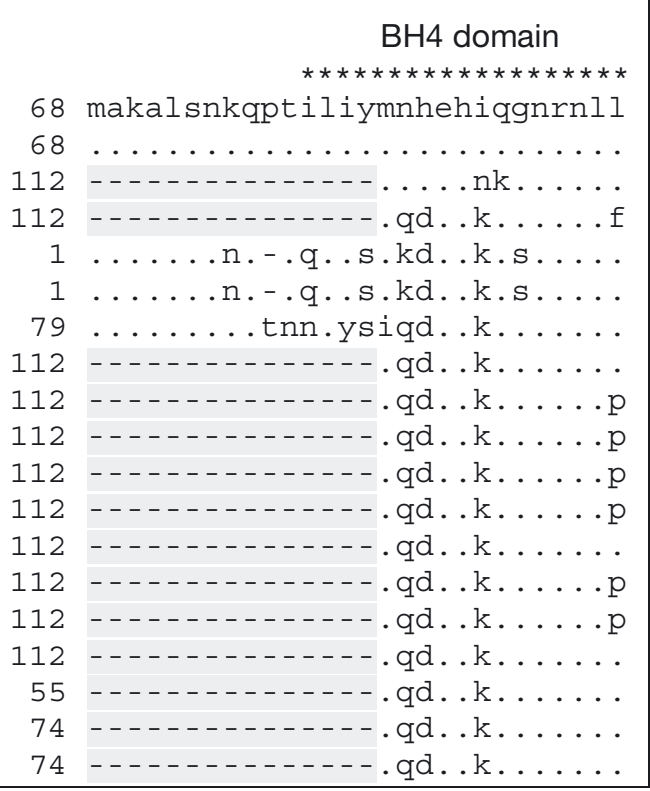

Fig. 3. (A) Nucleotide (nt) sequence alignment of all available VP5 sequences identifying deletion at position number 106 (arrow). (B) Amino acid (aa) sequence alignments of the same VP5 strains. Note strains that have the 106 deletion also have a 15 aa deletion at the N-terminal end (grey shading). (.) Identical bases/aa; (-) deleted nt residue/aa 
insertion at nucleotide position 111. A similar insertion was found in the Australian and New Zealand Aquabirnavirus isolates. The N1 strain has been demonstrated to produce VP5 (Håvarstein et al. 1990, Heppell et al. 1995), and was also the only IPNV sequence examined that did not contain a second methionine residue.

It is assumed that the initiation codon for any isolate exhibiting a deletion at nucleotide 106 is position 112, and for those with no deletion at 106, the initiation codon is at position 68. Alignments of VP5 aa sequences revealed that Australasian isolates were 133 aa in length, lacking 15 aa at the N-terminal end of full length IPNV VP5 sequences (VR299: Heppell et al. 1993; Jasper: Duncan \& Dobos 1986; N1: Håvarstein et al. 1990). Similarly sized VP5 proteins have been identified for Fr21, Can2 (Heppell et al. 1993) and Norwegian Sp strains (Santi et al. 2004), all of which also lack the $15 \mathrm{~N}$-terminal aa.

Hong et al. (2002) demonstrated that the full length VP5 protein, which is composed of domains $\mathrm{BH} 1, \mathrm{BH} 2$, $\mathrm{BH} 3$ and $\mathrm{BH} 4$, has an anti-apoptotic function. Loss or modification of domains $\mathrm{BH} 1$ and $\mathrm{BH} 2$ resulted in loss of this function. While these domains were intact for the Australasian isolates, aa sequence alignments (Fig. 3B) indicate that all truncated VP5 proteins lack the first 4 aa of the $\mathrm{BH} 4$ domain. The effect of this deletion on the function of VP5 is unclear.

While virulence of IPNV isolates has been linked to Segment A (Sano et al. 1992), no specific sequences or motifs have been identified that correlate with virulence. An attempt to determine specific markers of virulence was recently reported by Santi et al. (2004). They demonstrated that all pathogenic isolates studied encoded a truncated VP5 protein. However, the current study has shown that all Australasian strains also contain a truncated VP5 protein, despite the fact that these isolates were usually detected in healthy fish showing no overt signs of disease (Tisdall \& Phipps 1987, Crane et al. 2000). Therefore, the significance of a truncated VP5 protein in determination of virulence in salmon remains unclear. Other studies have shown that the role of VP5 in the expression of virulence is more complex and may be influenced by other viral and/or host factors (e.g. Santi et al. 2005). It is possible that the Australasian isolates may be pathogenic in other hosts or under different environmental or husbandry conditions. TAB has never been detected in any of the Tasmanian salmonid hatcheries and thus it has been assumed to originate in wild, non-salmonid fish populations. It is noteworthy that water temperatures in Tasmania are relatively high for salmonid aquaculture and stocking densities are kept relatively low in comparison to conditions in other salmon producing countries.
While the VP1 sequence was obtained as part of this study, a critical analysis has not been undertaken because VP1 encodes the RNA-dependent RNA polymerase and is likely to be highly conserved. At the aa level, all Australasian isolates were closely related. They showed greatest similarity to Sp (89\%) and were least similar to the Jasper isolate (80\%). However, there is limited sequence data available in GenBank for the VP1 protein.

\section{Development of a differential diagnostic test}

While aquatic birnaviruses have been isolated from both wild and farmed fish in Australasia, pathogenic IPNV remains exotic to this region. Thus, it was important for us to develop a diagnostic test that could differentiate Tasmanian Aquabirnavirus from pathogenic strains. To develop a PCR test that was pan-specific for aquatic birnaviruses, a set of generic primers, based on a nucleotide sequence alignment of Segment A from 13 exotic aquatic birnaviruses representing each genogroup and the 2 Australian and New Zealand isolates, was developed in conserved regions located on either side of a known variable region in the gene that encodes VP2. The forward primer was newly designed while the reverse primer was P10 designed by Blake et al. (2001a,b). This 'generic' PCR successfully detected all Serogroup A viruses tested, resulting in a $775 \mathrm{bp}$ product. However, neither of the Serogroup B viruses tested yielded a PCR product (data not shown). While it is recognised that only sequence analysis of the PCR product will provide a definitive diagnosis, the presence of a unique Cla1 restriction enzyme site within the PCR product for TAB enabled the development of a rapid test to differentiate the TAB PCR product from the PCR product of other Serogroup A aquatic birnaviruses. The 775 bp Aquabirnavirus PCR products from each of the 10 different isolates of $\mathrm{TAB}$ were digested by $C l a 1$, yielding 2 products (652 and $123 \mathrm{bp}$ ). No digestion occurred with the other aquatic birnaviruses that were examined in this study, including the 2 closely related New Zealand isolates (Fig. 4). For regional laboratories that may not have ready access to sequencing facilities, this technique provides a rapid means of tentatively characterising any specific product from the generic aquatic birnavirus PCR. Unfortunately, no MABs were available for examinination with this test, but a review of sequence alignments indicated that, theoretically, this test would also differentiate TAB from any marine birnaviruses as all of the latter lack the ClaI restriction site within the generic amplified product. 


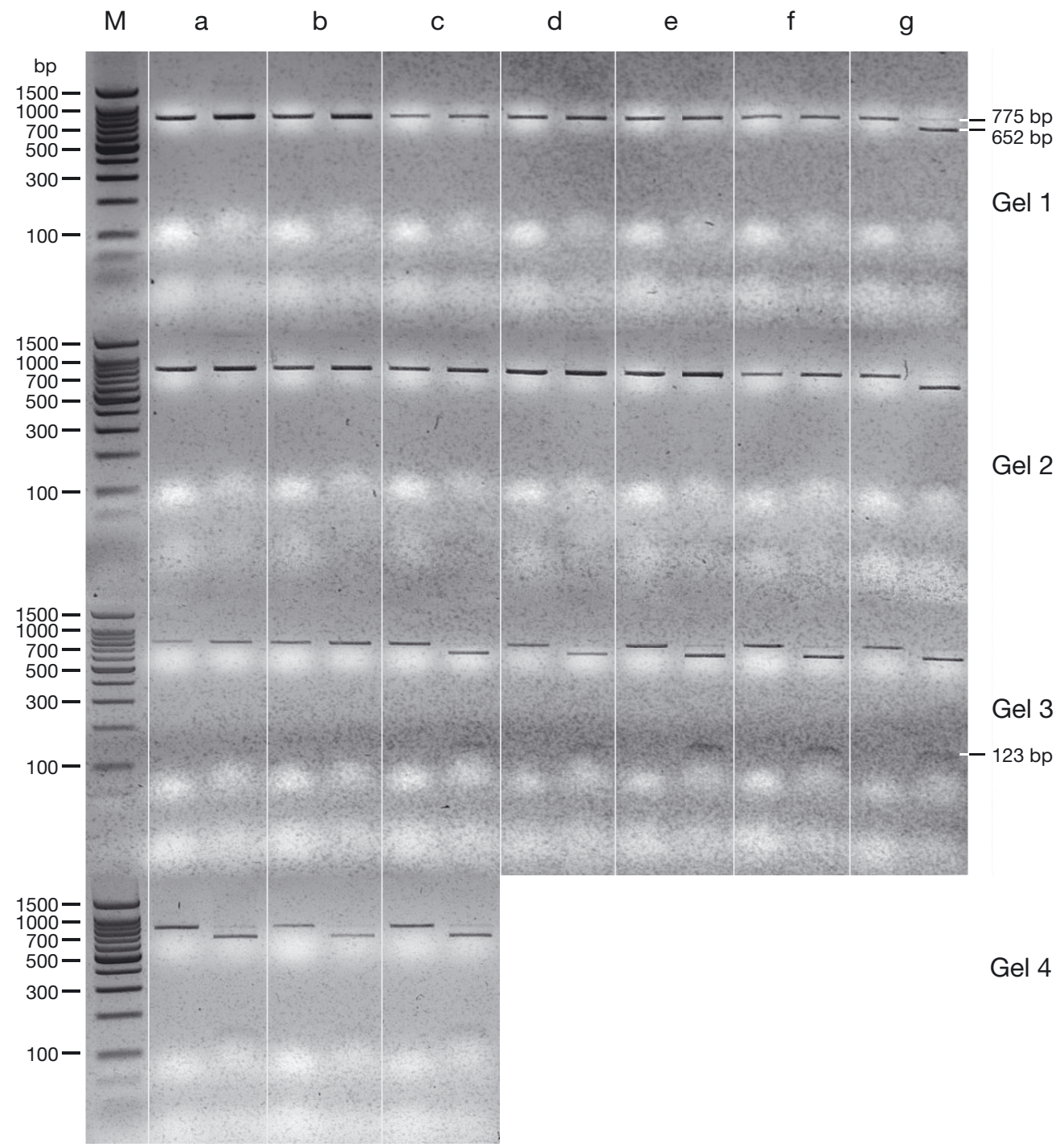

Fig. 4. ClaI digestion patterns of generic PCR products. The generic PCR products of various infectious pancreatic necrosis virus (IPNV) and Australasian aquabirnavirus isolates were digested with ClaI. For each sample (a to g), the uncut (left) and cut (right) samples were run next to each other to demonstrate fragment size shift. Gel 1: (a) West Buxton; (b) Jasper; (c) VR299; (d) Erwin; (e) He; (f) Canada (Can) 2; (g) TAB98. Gel 2: (a) Can 3; (b) Can 1; (c) Te; (d) Ab; (e) NZ6; (f) NZ10; (g) TAB02. Gel 3: (a) Sp; (b) DPL; (c) TAB Atlantic salmon, Macquarie Harbour (2001 isolate); (d) TAB Atlantic salmon, Hideaway Bay (1998 isolate); (e) TAB Atlantic salmon, Hideaway Bay (1998 isolate); (f) TAB rainbow trout, Macquarie Harbour (1998 isolate); (g) TAB rainbow trout, Macquarie Harbour (2001 isolate). Gel 4: (a) TAB cod, Macquarie Harbour (1998 isolate); (b) TAB flounder, Macquarie Harbour (1998 isolate); (c) TAB baitfish, Macquarie Harbour (1998 isolate). M: 100 bp DNA ladder (Promega). 775 bp is equivalent to the undigested amplicon. The 652 and $123 \mathrm{bp}$ are the sizes of the 2 cut (digested) pieces

Acknowledgements. We gratefully acknowledge the generosity of: M. Hine and R. Morrison (National Centre for Disease Investigation, Upper Hutt, New Zealand) for supply of the New Zealand aquatic birnavirus isolates; B. L. Nicholson (University of Maine, USA) for providing the DPL isolate; B. Hill and K. Way (Weymouth Laboratory, CEFAS, Dorset, UK) for the Erwin isolate of IPNV; and, finally, A. Pye and A. R. Gould (CSIRO $\mathrm{AAHL}$ ) for sequencing and sharing the partial sequence of the TAB Segment B gene, respectively. The authors also thank F. Filippi (CSIRO AAHL) for his expert assistance with graphic design. This study was supported by funding from the FRDC on behalf of the Australian Government (FRDC Project 2001/620 Aquatic Animal Health Subprogram: Development of improved procedures for the identification of aquatic birnaviruses).

\section{LITERATURE CITED}

Ahne W (1994) Viral infections of aquatic animals with special reference to Asian aquaculture. Annu Rev Fish Dis 4: 375-388

Anderson CD (1995) Surveillance for fish diseases. Surveillance 22:13

Attoui H, Billoir F, Cantaloube JF, Biagini P, de Micco P, de Lamballerie X (2000) Strategies for the sequence determination of viral dsRNA genomes. J Virol Methods 89: $147-158$

Bain N, Gregory A, Raynard RS (2008) Genetic analysis of infectious pancreatic necrosis virus from Scotland. J Fish Dis 31:37-47 
Bernard J, Brémont M (1995) Molecular biology of fish viruses: a review. Vet Res 26:341-351

Blake S, Ma JY, Caporale DA, Jairath S, Nicholson BL (2001a) Phylogenetic relationships of aquatic birnaviruses based on the deduced amino acid sequences of genome segment A cDNA. Dis Aquat Org 45:89-102

Blake S, Ma JY, Caporale DA, Jairath S, Nicholson BL (2001b) Erratum. Phylogenetic relationships of aquatic birnaviruses based on the deduced amino acid sequences of genome segment A cDNA. Dis Aquat Org 46(2)

Bruslind LD, Reno P (2000) Virulence comparisons of three Buhl-subtype isolates of infectious pancreatic necrosis virus in brook trout fry. J Aquat Anim Health 12:301-315

Chung H, Lee S, Lee H, Lee D, Kim Y (1994a) Nucleotide sequence analysis of the VP2-NS-VP3 gene of infectious pancreatic necrosis virus DRT strain. Mol Cells 4:349-354

Chung H, Lee S, Soo-Young K, Lee H (1994b) Nucleotide sequence analysis of the RNA-dependent RNA polymerase gene of infectious pancreatic necrosis virus DRT strain. J Microbiol Biotechnol 4:264-269

- Crane MStJ, Hardy-Smith P, Williams LM, Hyatt AD and others (2000) First isolation of an aquatic birnavirus from farmed and wild fish species in Australia. Dis Aquat Org 43:1-14

Delmas B, Kibenge FSB, Leong JC, Vakharia VN, Wu JL (2005) Birnaviridae. In: Fauquet CM, Mayo MA, Maniloff J, Desselberger U, Ball LA (eds) Virus taxonomy: classification and nomenclature of viruses. 8th Report of the International Committee on the Taxonomy of Viruses. Elsevier, London, p 561-569

Dixon PF, Ngoh GH, Stone DM, Chang SF, Way K, Kueh SLF (2008) Proposal for a fourth aquabirnavirus serogroup. Arch Virol 153:1937-1941

Dobos P (1995) The molecular biology of infectious pancreatic necrosis virus (IPNV). Annu Rev Fish Dis 5:25-54

> Dobos P, Hill BJ, Hallet R, Kells DT, Becht H, Teninges D (1979) Biophysical and biochemical characterisation of five animal viruses with bisegmented double-stranded RNA genomes. J Virol 32:593-605

> Duncan R, Dobos P (1986) The nucleotide sequence of infectious pancreatic necrosis virus (IPNV) dsRNA segment A reveals one large ORF encoding a precursor polyprotein. Nucleic Acids Res 14:5934

> Duncan R, Nagy E, Krell PJ, Dobos P (1987) Synthesis of the infectious pancreatic necrosis virus polyprotein, detection of virus-encoded protease and fine structure mapping of genome segment A coding regions. J Virol 61:3655-3664

> Duncan R, Mason CL, Nagy E, Leong JA, Dobos P (1991) Sequence analysis of infectious pancreatic necrosis virus genome segment B and its encoded VP1 protein: a putative RNA-dependent RNA polymerase lacking the GlyAsp-Asp motif. Virology 181:541-552

> Håvarstein LS, Kalland KH, Christie KE, Endresen C (1990) Sequence of the large double-stranded RNA segment of the N1 strain of infectious pancreatic necrosis virus: a comparison with other Birnaviridae. J Gen Virol 71: 299-308

Heppell J, Berthiaume L, Tarrab E, LeComte J, Arella M (1992) Evidence of genomic variations between infectious pancreatic necrosis virus strains determined by restriction fragment profiles. J Gen Virol 73:2863-2870

> Heppell J, Berthiaume L, Corbin F, Tarrab E, LeComte J, Arella M (1993) Comparison of amino acid sequences deduced from a cDNA fragment obtained from infectious pancreatic necrosis virus (IPNV) strains from different serotypes. Virology 195:840-844

Heppell J, Tarrab E, LeComte J, Berthiuame L, Arella M
(1995) Strain variability and localization of important epitopes on the major structural protein (VP2) of infectious pancreatic necrosis virus. Virology 214:40-49

Hill BJ, Way K (1995) Serological classification of infectious pancreatic necrosis (IPN) virus and other aquatic birnaviruses. Annu Rev Fish Dis 5:55-77

> Hong JR, Gong HY, Wu JL (2002) IPNV VP5, a novel antiapoptosis gene of the Bcl-2 family regulates $\mathrm{Mcl}-1$ and viral protein expression. Virology 295:217-229

John KR, Richards RH (1999) Characteristics of a new birnavirus associated with a warm-water fish cell line. J Gen Virol 80:2061-2065

> Lambden PR, Cooke SJ, Caul EO, Clarke IN (1992) Cloning of noncultivatable human rotavirus by single primer amplification. J Virol 66:1817-1822

Lipipun V, Caswell-Reno P, Hsu YL, Wu JL and others (1989) Antigenic analysis of Asian aquatic birnavirus isolates using monoclonal antibodies. Fish Pathol 24:155-160

- Magyar G, Dobos P (1994) Evidence for the detection of the infectious pancreatic necrosis virus polyprotein and the 17 -kDa polypeptide in infected cells and the NS protease in purified virus. Virology 204:580-589

> Nishizawa T, Kinoshita S, Yoshimizu M (2005) An approach for genogrouping of Japanese isolates of aquabirnaviruses in a new genogroup, VII, based on the VP2/NS junction region. J Gen Virol 86:1973-1978

> Olesen NJ, Bloch B, Mellergaard S (1988) Isolation of an IPNlike virus belonging to the serogroup II of the aquabirnaviruses from dab, Limanda limanda L. J Fish Dis 11: 449-451

Petit S, Lejal N, Huet JC, Delmas B (2000) Active residues and viral substrate cleavage sites of the protease of the birnavirus infectious pancreatic necrosis virus. J Virol 74: 2057-2066

Potgieter AC, Steele AD, van Dijk AA (2002) Cloning of complete genome sets of six dsRNA viruses using an improved cloning method for large dsRNA genomes. J Gen Virol 83: 2215-2223

Reno PW (1999) Infectious pancreatic necrosis and associated aquatic birnaviruses. In: Woo PTK, Bruno DW (eds) Fish diseases and disorders, Vol 3. Viral, bacterial and fungal infections, CABI Publishing, Wallingford, p 1-55

> Sano M, Okamoto N, Fukuda H, Saneyoshi M, Sano T (1992) Virulence of infectious pancreatic necrosis virus is associated with the larger RNA segment (RNA segment A). J Fish Dis 15:283-293

> Santi N, Vakharia VN, Evensen $\varnothing$ (2004) Identification of putative motifs involved in the virulence of infectious pancreatic necrosis virus. Virology 322:31-40

Santi N, Sandtrø A, Sindre H, Song H and others (2005) Infectious pancreatic necrosis virus induces apoptosis in vitro and in vivo independent of VP5 expression. Virology 342: $13-25$

Shivappa RB, Song H, Yao K, Aas-Eng A, Evensen Ø, Vakharia VN (2004) Molecular characterization of Sp serotype strains of infectious pancreatic necrosis virus exhibiting differences in virulence. Dis Aquat Org 61: $23-32$

Suzuki S, Kimura M, Kusuda R (1998) The complete nucleotide sequence of the polyprotein and VP5 gene of a marine birnavirus. Fish Sci 64:428-433

Tisdall DJ, Phipps JC (1987) Isolation and characterisation of a marine birnavirus from returning quinnat salmon (Oncorhynchus tshawytscha) in the south island of New Zealand. NZ Vet J 35:217-218

> Vreede FT, Cloete M, Napier GB, van Dijk AA, Viljoen GJ (1998) Sequence-independent amplification and cloning 
of large dsRNA virus genome segments by poly(dA)oligonucleotide ligation. J Virol Methods 72:243-247

Weber S, Fichtner D, Mettenleitner TC, Mundt E (2001) Expression of VP5 of infectious pancreatic necrosis virus strain VR299 is initiated at the second in-frame start codon. J Gen Virol 82:805-812

Wolf K, Snieszko SF, Dunbar CE, Pyle E (1960) Virus nature of infectious pancreatic necrosis in trout. Proc Soc Exp Biol Med 104:105-108

Editorial responsibility: Catherine Collins, Aberdeen, UK
Yao K, Vakharia VN (1998) Generation of infectious pancreatic necrosis virus from cloned cDNA. J Virol 72: 8913-8920

Zhang CX, Suzuki S (2003) Comparison of the RNA polymerase genes of marine birnavirus strains and other birnaviruses. Arch Virol 148:745-758

Zhang CX, Suzuki S (2004) Aquabirnaviruses isolated from marine organisms form a distinct genogroup from other aquabirnaviruses. J Fish Dis 27:633-643

Submitted: May 26, 2009; Accepted: August 23, 2010

Proofs received from author(s): November 23, 2010 